Al-Huquq: Journal of Indonesian Islamic Economic Law, 1 (2), 2019: 102-121

ISSN: 2715-0003; E-ISSN 2714-5514

DOI: http://dx.doi.org/10.19105/al-huquq.v1i2.3087

\title{
Peran Zakat dan Pajak dalam Menyelesaikan Masalah Perekonomian Indonesia
}

\author{
M. Haris Hidayatulloh \\ (Institut Agama Islam Negeri Madura, Jl. Raya Panglegur KM. 04 \\ Pamekasan-69371, Jawa Timur Indonesia)
}

\begin{abstract}
Abstrak:
Kemiskinan masih menjadi permasalahan Indonesia yang belum terselesaikan. Ditribusi kekayaan yang tidak merata menjadi penyebab naik turunnya tingkat kemiskinan. Disisi lain, permasalahan yang dihadapi sedang dihadapi Indonesia adalah bidang infrastruktur. Rendahnya kualitas infrastrktur menghambat laju perekonomian negara, infrastruktur merupakan salah satu media dalam yang yang dilalui segala kegiatan termasuk juga didalamnya kegiatan perekonomian. Dua permasalahan ini menyebabkan perekonomian Indonesia sulit untuk berkembang. Jadi dengan demikian rumusan masalah yang diangkat dalam penelitian ini adalah bagaimana zakat dan pajak berperan dalam menyelesaikan permasalahan perekonomian Indonesia?. Tujuan dari penelitian ini adalah untuk mengetahui solusi dari permasalahan yang ada melalui zakat dan pajak. Dalam islam, zakat digunakan sebagai pendistribusi kekayaan dari pemberi (muzakki) kepada penerima (mustahik). Sedangkan dalam peraturan negara dana yang diperoleh dari pajak salah satunya dialokasikan pada pengembangan infrastruktur. Zakat dan pajak berperen penting pada peekonomian negara, zakat menyelasakan masalah secara mikro sedangkan pajak menyelasaikan masalah secara makro. (Poverty remains an unresolved Indonesian problem. Unevenly distributed wealth is the cause of poverty. On the other hand, the problems faced are facing Indonesia is the field of infrastructure. Low quality infrastructure inhibits the rate of economy of the country, infrastructure is one of the media in which all activities are traversed as well as economic activities. These two problems cause the Indonesian economy to be difficult to thrive. So, thus the formulation of the problem raised in this research is how zakat and tax play a role in resolving Indonesia's economic problem?. The purpose of this
\end{abstract}

https://creativecommons.org/licenses/by-nc/4.0/

Copyright (c) 2019 by al-huquq. All Right Reserved

Author Correspondence: m.harishidayatulloh@iainmadura.ac.id 
research is to know the solution of the problems that exist through zakat and tax. In Islam, Zakaah is used as a distribution of wealth from The Giver (muzakki) to the recipient (mustahik). While in the State regulation the funds obtained from the tax are allocated to the development of infrastructure. Zakat is a solution in micro scope while tax is a solution in the scope of macro.)

Kata Kunci:

Gadai Tanah; Kurs Harga Emas; Hukum Islam; Desa

Plakpak

\section{Pendahuluan}

Kemiskinan adalah suatu keadaan dimana sumber pemenuhan kebutuhan dasar baik sandang, pangan, papan, maupun kesehatan dan Pendidikan dasar berada pada titik rendah atau kurang. ${ }^{1}$ Bila melihat data kemiskinan 15 tahun terakhir menunjukkan adanya kenaikan maupun penurunan pada tahuntahun tertentu. Berikut adalah data kemiskinan dari badan pusat statistik. ${ }^{2}$ Perkembangan jumlah dan persentase penduduk miskin di Indonesia, 2003-2018

Jumlah dan Persentase Penduduk Miskin, 2003-September 2018

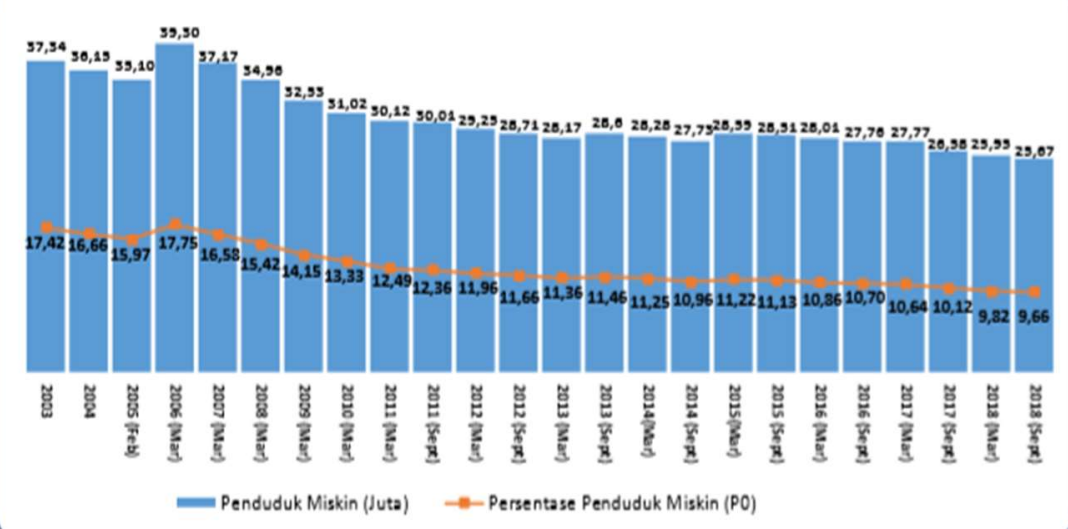

${ }^{1}$ M. Amien Rais, Kemiskinan Dan Kesenjangan Di Indonesia, (Jakarta: Aditya Media, 1995), h. 9.

${ }^{2}$ https://www.bps.go.id, diakses 2 juli 2019. 
Sumber : Badan Pusat Statistik

Dari gambar diatas dapat dijelaskan terjadi penurunan tingkan kemiskinan pada tahun 2003 - 2005 yaitu berada pada angka $15,97 \%$ dari jumlah penduduk di Indonesia dan mengalami peningkatan kembali pada 2006 menjadi 17,75\%, dan sejak tahun 2007 - 2016 terjadi penurunan secara sigifikan. Namun penurunan tersebut belum menunjukkan bahwa angka kemiskinan di Indonesia berada pada titik rendah, karena masih dalam angka 9,66\% atau sejumlah 25,67 juta jiwa.

Dalam laporan terbaru World Economic Forum (WEF), dijelaskan bahwa kendala infrastruktur di indonesia diantaranya adalah kualitas jalan, bandara, dan pelabuhan serta pasokan listrik yang rendah, kendala lainnya adalah rendahnya penguasaan terhadap teknologi dan kegiatan inovasi yang berdampak pada kesiapan teknologi dan inovasi pada pengembangan infrastruktur negara. ${ }^{3}$

Data lain yang mejelaskan rendahnya infrastruktur di indonesia dilaporkan oleh International Institute For Manajement Development (IMD) yaitu pada penelitiannya yang dilakukan pada tahun 2011. Dari hasil penelitian tersebut Indonesia berada pada peringkat 37 dari 59 negara. Rendahnya kualitas infrastruktur dasar, infrastruktur sains, infrastruktur teknis, Pendidikan, kesehatan dan lingkungan hidup yang menjadi penyebab Indonesia tidak dapat bersaing dengan negara-negara lainnya sehingga berada pada pringkat yang rendah. ${ }^{4}$

Dari dua permasalahan yang ada ditemukan faktor utama yang menjadi sumber terjadinya permaslahan-permasalahan yang ada yaitu minimnya pedapatan masyarakat dan distribusi kekayaan yang tidak merata yang menyebabkan kemiskinan dan minimnya pendapatan negara yang menyebabkan rendahnya kualitas pembangunan infrastruktur negara.

Setelah permasalahan ditemukan, maka selanjutnya yang perlu dicari adalah solusi untuk mengatasi permasalahan tersebut.

3 Novi Maryaningsih, Oki Hermansyah, dan Myrnawati Savitri. 2014. Pengaruh Infrastruktur Terhadap Pertumbuhan Ekonomi Indonesia, Buletin Ekonomi Moneter dan Perbankan, Volume 17, Nomor 1, Juli 2014.

4 Ibid. 
Dalam islam, regulasi atau media pendistribusi kekayaan adalah zakat, sedangkan dalam regulasi negara mengenal pajak sebagai sumber utama penerimaan negara. lalu bagaimana zakat dan pajak menyelesaikan permasalahan ekonomi nasional yang ada saat ini?

\section{Tinjauan Umum tentang zakat dan pajak}

\section{Definisi Dan Dasar Hukum Zakat}

Dalam tinjauan secara bahasa, zakat berasal dari kata " $z a k a$ " dengan arti tumbuh dan berkembang. Sedangkan secara istilah zakat dapat dirtikan sebagai sebagian harta tertentu yang wajib dikeluarkan oleh seseorang (muzakki) dan diberikan kepada orang-orang yang berhak menerima zakat (mustahik). ${ }^{5}$ Secara umum zakat didefinisikan sebagai sejumlah harta yang dikeluarkan oleh orang-orang tertentu dengan syarat-syarat tertentu dan disalurkan kepada pihak tertentu yang terbagi dalam delapan golongan (asnaf). ${ }^{6}$

Dalam al-quran perintah membayar zakat dijelaskan pada QS. Al-Baqarah : 43 dan 110, Al-Maidah : 55 serta masih banyak lagi ayatayat al-quran yang menjelaskan tentang perintah membayar zakat. Sebagian dari tersebut berbunyi:

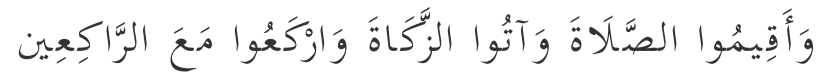

"Dan dirikanlah shalat, tunaikanlah zakat dan ruku'lah beserta orangorang yang ruku'. (. Al-Baqarah: 43)"

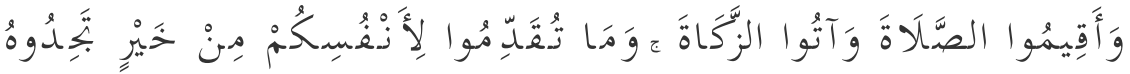

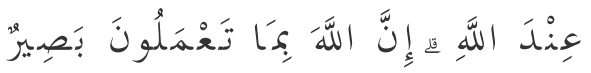

"Dan dirikanlah shalat dan tunaikanlah zakat. dan kebaikan apa saja yang kamu usahakan bagi dirimu, tentu kamu akan mendapat pahala nya pada sisi Allah. Sesungguhnya Alah Maha melihat apa-apa yang kamu kerjakan.( Al-Baqarah: 110)"

\footnotetext{
5 Ali Nuruddin. Zakat Sebagai Instrumen Dalam Kebijakan Fiskal, (Jakarta: Pt Raja Grafindo Persada, 2006), hal. 6

${ }^{6}$ Moh. Rowi Latief \& A. Shomad Robith, Tuntunan Zakat Praktis, (Surabaya: Indah, 1987), hal.13 lihat juga Erie Hariyanto and Moh Ali Al-Humaidy, "Pelaksanaan Corporate Social Responsibility dan Zakat Perusahaan Perbankan Syari ' ah di Madura, “ Jurnal Hukum dan Pembangunan 49, no. 3 (2019): hal. 688-709
} 


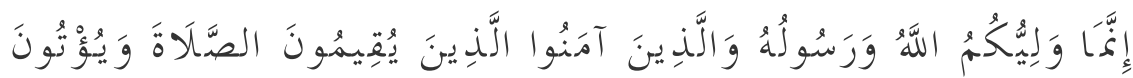

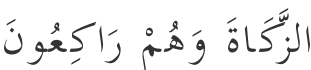

"Sesungguhnya penolong kamu hanyalah Allah, Rasul-Nya, dan orang-orang yang beriman, yang mendirikan shalat dan menunaikan zakat, seraya mereka tunduk (kepada Allah). (Al-Maidah : 55)"

Seperti penjelasan diatas bahwa zakat diwajibkan atas pihak tertentu (muzakki), begitu juga penerima zakat adalah orang tertentu (mustahik). Dalam Al-Quran mustahik zakat dikelompokkan atas delapan asnaf yang dijelaskan pada QS. At-Taubah : 60 yang berbunyi:

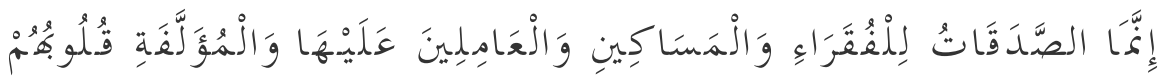

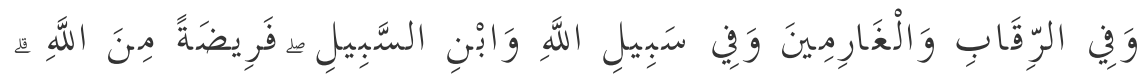

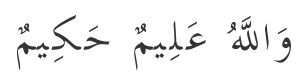

"Sesungguhnya zakat-zakat itu, hanyalah untuk orang-orang fakir, orangorang miskin, pengurus-pengurus zakat, Para mu'allaf yang dibujuk hatinya, untuk (memerdekakan) budak, orang-orang yang berhutang, untuk jalan Allah dan untuk mereka yuang sedang dalam perjalanan, sebagai suatu ketetapan yang diwajibkan Allah, dan Allah Maha mengetahui lagi Maha Bijaksana. (At-taubah: 60)"

\section{Jenis dan ketentuan zakat}

Secara umum zakat terbagi atas dua jenis yaitu zakat fitrah dan zakat maal. Zakat fitrah merupakan zakat yang wajib dibayarkan oleh setiap umat muslim pada saat bulan ramhadan hingga sebelum memasuki idul fitri. Zakat fitrah dapat berupa uang atau bahan pokok (makanan) yang umum dikonsumsi masyarakat susuai dengan takaran yang telah ditetapkan atas ijtihad para ulama. Sedangkan zakat maal atau dapat kita pahami sebaga zakat atas harta kekayaan merupakan zakat yang wajib dikeluarkan/dibayarkan oleh setiap muslim baik telah maupun belum baligh, berakal maupun tidak atas harta yang dimiliki ketika telah mencapai syarat-syarat dan ketentuan yang telah ditentukan.

Terdapat beberapa pendapat para ulama tentang harta yang wajib dikeluarkan zakatnya, diantaranya adalah empat jenis harta 
wajib zakat menurut Ibnul Qayyim Al-Jauziyyah yaitu, barang berharga (emas dan perak), hewan ternak, hasil pertanian, dan harta perdagangan. ${ }^{7}$ Sedangkan pendapat dari Yusuf Qardhawi lebih memandang pada perkembangan zaman atau kondisi kontemporer yang berkembang di kalangan masyarakat, sehingga dengan demikian Yusuf Qardhawi berpendapat bahwa harta yang wajib dikeluarkan zakatnya terbagi atas sepuluh bagian, yaitu: emas dan perak, uang, pertanian, perdagangan, binatang ternak, madu dan produksi hewani, investasi pabrik dan Gedung serta sejenisnya, barang tambang dan hasil laut, pencarian dan profesi, saham dan obligasi. ${ }^{8}$

Dalam Perundang-Undangan Negara Republik Indonesia Nomor 23 Tahun 2011 Pasal 4 Ayat 1, harta yang wajib dikeluarkan zakatnya meliputi: a) Emas, perak, dan logam muliah lainnya, b) Uang dan surat berharga lainnya, c) Perniagaan, d) Pertanian, perkebunan kehutanan, e) Peternakan dan perikanan, f) Pertambangan, g) Perindustrian, h) Pendapatan dan jasa, i) Rikaz. ${ }^{9}$

Kewajiban dikeluarkannya zakat atas harta yang dimiliki apabila telah mencapai atau memenuh syarat-syarat yang ditentukan, syarat-syarat tersebut adalah:

a. Kepemilikan penuh atau sempurna

Kepemilikan terhadap harta yang menunjukkan bahwa pemilik dapat mempergunakan dan mengambil manfaat secara penuh atas barang yang dimilikinya.

b. Harta berkembang

Dalam hal ini harta yang produktif atau berpotensi produktif, harta dapat berkembang apabila digunakan dalam usaha.

\footnotetext{
7 Didin Hafidhuddin. Zakat dalam Perekonomian Modern. (Jakarta : Gema Insani Press, 2002). Hal. 28 lihat juga Erie; Suyudi Mohammad Hariyanto, "View of Jual Beli Benda Wakaf Untuk Pembangunan Masjid Istiqlal Di Desa Palengaan Daja Pamekasan," accessed December 2, 2019,hal. 18

8 Yusuf Qardhawi. Kiat Sukses Mengelola Zakat, Terj. Asmuni Solihan Zamakhsyari, (Jakarta: Media Dakwah, 1997) hal. 167, 501

9 Undang-Undang Republik Indonesia Nomor 23 Tahun 2011 Tentang Pengelolaan Zakat, Pasal 4 ayat 1
} 


\section{c. Nisab}

Harta wajib dikeluarkan zakatnya bila sudah mencapai nisab, nisab adalah jumlah minimum dari harta wajib zakat

d. Kebutuhan pokok yang terpenuhi

Kebutuhan minimal yang yang harus dipenuhi dalam kebutuhan hidup manusia (kebutuhan primer/Dharuriyah)

e. Terbebas dari hutang

Hutang yang dimiliki seseorang menjadi pengurang pada nisab harta wajib zakatnya, jika harta wajib zakat yang dimiliki tidak mencapai nisab setelah dikurangi hutangnya maka harta tersebut tidak wajib untuk dikeluarkan zakatnya.

f. haul

Barang berharga (emas, uang, hewan ternak, harta benda yang diperdagangkan, dan lain sebagainya) wajib dikeluarkan zakatnya bila kepemilikannya telah mencapai satu tahun penuh (haul). Sedangkan harta hasil pertanian, buah-buahan, dan barang temuan (rikaz) atau barang lain sejenisnya tidak disyaratkan haul atas kepemilikannya. ${ }^{10}$

\section{Fungsi Zakat}

Ruang lingkup zakat tidak hanya mencakup pada aspek keuangan saja, melainkan pada apek kehidupan lainnya, diantaranya adalah ekonomi, politik, sosial, moral serta agama. Zakat dalam aspek keuangan karena zakat layaknya pajak yang telah ditentukan pembayar maupun jumlahnya, zakat dalam aspek ekomoni karena zakat dapat menjadi sarana pendistribusian kekayaan, zakat dalam aspek politik karena pada dazarnya pengelolaan zakat dilakukan oleh lembaga yang dinaungi oleh negara baik pemungutan maupun pendistribusiannya, zakat dalam aspek moral karena zakat dapat melatih jiwa manusia untuk empati antar sesama, sedangkan zakat dalam aspek agama karena zakat diperintahkan oleh Allah SWT sebagai pencipta dan melaksanakan perintahnya merupakan salah satu ibadah yang menujukkan tingkat keimanan seorang hamba atas penciptanya.

${ }^{10}$ Ahmad Hadi Yasin. Panduan zakat praktis (hak cipta dompet dhuafa republika). www.dompetdhuafa.org. Diakses 8 juli 2017. 
Menurut Monzer Kahf tercapainya keadilan social ekonomi merupakan tujuan zakat. Zakat dapat digunakan sebagai sarana distribusi kekayaan dari pemberi zakat (muzakki) kepada penerima zakat (mustahik). ${ }^{11}$ Dengan demikian zakat juga dapat digunakan sebagai media pendorong menuju tercapainya keseimbangan ekonomi secara umum, seperti yang dijelaskan diatas bawah zakat merupakan implementasi keadilan, yang bertujuan mehilangkan jurang pemisah antara muzakki dan mustahiknya.

Selain tercapainya keadilan sosial ekonomi, terdapat sembilan lainnya fungsi zakat yang dikemukankan oleh Ali Dan Zaman. Diantaranya adalah sebagai berikut :

a. Mengangkat derajat fakir dan miskin.

b. Menyelesaikan permasalahan perekonomian mustahik

c. Menjalin tali silaturahmi dan persaudaraan antara umat islam.

d. Menumbuhkan sifat dermawan

e. Menghindari kecemburuan sosial (iri dan dengki) antara orang kaya dan orang yang tidak mampu.

f. Distribusi kekayaan yang merata, sehingga dapat menghilangkan kesenjangan sosial antar masyarakat.

g. Menumbuhkan rasa tanggung jawab terhadap diri sendiri, harta yang dimiliki, serta tanggung jawab terhadap sosial.

h. Melatih diri untuk disiplin dalam melaksanakan kewajiban dan menyerahkan hak orang lain atas harta yang dimilikinya.

i. Sarana menciptakan keadilan sosial dengan pemerataan pendapatan. ${ }^{12}$

\section{Definisi Dan Dasar Hukum Pajak}

Secara bahasa, Islam mengenal pajak berasal dari kata "dharibah" yang berarti dana yang ditarik dari rakyat oleh

\footnotetext{
${ }^{11}$ Monzer Kahf, Potential Effects Of Zakah On Government Budget, dalam IIUM Journal of Economics \& Management 5, No. 1. Tahun 1997.

12 Mohammad Daud Ali, Sistem Ekonomi Islam Zakat dan Wakaf, (Jakarta : UI Press, 1988), h. 21 dan Hasanuz Zaman, S. M., Islamic Criteria For The Distribution Of Tax Burden (The Mix of Direct and Indirect Taxes and The Offsetting Fuction of Zakat), dalam Journal of Islamic Economics, Vol. 3, No. 1. Januari Tahun 1993.
} 
pemerintah atau penarik pajak. Sedangkan pajak dalam pasal $23 \mathrm{~A}$ UUD 1945 pajak dedefinisikan kontribusi yang dikenakan kepada seluruh Warga Negara Indonesia, warga negara asing dan warga yang tinggal secara kumulatif 120 hari di wilayah Indonesia dalam jangka waktu dua belas bulan. ${ }^{13}$

Dari definisi diatas penulis menyimpulkan bahwa pajak merupakan iuran wajib bagi warga negara yang dipungut sesuai dengan jenis dan tarifnya yang telah diatur dalam UUD. 1945 yang nantinya hasil dari pungutan tersebut akan digunakan untuk penyelenggaraan kegiatan pemerintahan ataupun untuk pembangunan negara.

Pada masa pemerintahan Rasulullah pajak yang diterapkan berupa pajak tanah (kharaj), pajak atas jaminan keamanan yaitu pajak yang dipungut dari non-muslim yang meminta perlindungan/keamanan dibawah pemerintahan muslim (jizyah), dan pajak perdagangan atau bea cukai (usyr). Di Indonesia ketentuanketentuan membayar pajak diatur dalam undang-undang dasar 1945 dimana sebagian isinya seperti yang dijelaskan diatas.

\section{Jenis dan ketentuan pajak}

Secara umum, pengelolaan pajak di indonesia terbagi atas dua bagian yaitu pajak pusat dan pajak daerah. Pajak pusat adalah pajakpajak yang dikelola oleh Pemerintah Pusat, dalam hal ini berada di bawah naungan Direktorat Jendral Pajak-Departemen Keuangan. Pajak daerah adalah pajak yang dipungut dan dikelola oleh pemerintah daerah.

Pajak pusat meliput beberapa jenis pajak, yaitu:

a. Pajak penghasilan

Pajak penghasilan dipungut dari perseorangan atau badan atas penghasilan yang diterimanya selama satu tahun. ${ }^{14}$ Adapun obyek dari pajak penghasilan adalah sebagai berikut:

1) Gaji, komisi, upah, bonus, uang pensiun atau imbalan lainnya untuk pekerjaan yang dilakukan.

13 https://id.wikipedia.org/wiki/Perpajakan_di_Indonesia. diakses 17 juli 2017

14 Undang-Undang Republik Indonesia Nomor 7 Tahun 1983 Tentang Pajak Penghasilan, Pasal 1 
2) Honorarium, penghargaan, hadiah undian.

3) Laba bruto usaha

4) Keuntungan atas penjualan atau atas pengalihan harta. 15

b. Pajak pertambahan nilai.

Pajak pertambahan nilai adalah pajak yang

dikenakan atas konsumsi barang kena pajak atau jasa kena pajak di daerah pabean (wilayah republik Indonesia yang meliputi wilayah barat, perairan, dan ruang udara serta tempat-tempattertentu di zona ekonomi eksklusif). ${ }^{16}$

c. Pajak penjualan atas barang mewah (PPn BM)

Barang yang tegolong barang mewah dikenakan pajak lain, yaitu pajak penjualan atas barang mewah (PPn BM). PPn BM dikenakan hanya satu kali saja pada saat penyerahan barang oleh pengusaha atau penjual. ${ }^{17}$ Adapun kriteria barang mewah diantaranya adalah sebagai berikut:

1) Barang mewah adalah barang yang tidak termasuk dalam barang kebutuhan pokok.

2) Barang mewah hanya dikonsumsi oleh kalangan masyarakat tertentu.

3) Barang mewah pada umumnya dikonsumsi oleh masyarakat dengan penghasilan yang tinggi.

4) Barang mewah dikonsumsi dapat menujukkan status. ${ }^{18}$

d. Bea Meterai

Bea Meterai adalah pajak yang dikenakan atas dokumen. ${ }^{19}$ Materai merupakan lembaran kertas yang digunakan sebagai bukti atas kesepakatan kedua belah pihak.

${ }^{15}$ Ibid, Pasal 4

16 Undang-Undang Republik Indonesia Nomor 18 Tahun 2000 Tentang Perubahan Kedua Atas Undang-Undang Nomor 8 Tahun 1983 Tentang Pajak Pertambahan Nilai Barang Dan Jasa Dan Pajak Penjualan Atas Barang Mewah, Pasal 1 ayat 1.

17 Ibid, Pasal 5 ayat 2.

${ }^{18}$ http:/ / pelayanan-pajak.blogspot.co.id, diakses 8 juli 2017. 
e. Pajak Bumi dan Bangunan (PBB)

Pajak Bumi dan Bangunan (PBB) adalah pajak yang dipungut dari orang atau badan atas pemanfaatan atau kepemilikan tanah maupun bagunan. PBB dikelola oleh pemerintah pusat, namun penerimaannya dilaksanakan oleh Pemerintah Daerah baik Propinsi maupun Kabupaten/Kota. Adapun tanah dan bangunan yang tidak kena pajak adalah sebagai berikut:

1) Digunakan untuk kepentingan umum (tempat ibadah, sosial, kesehatan, Pendidikan dan kebudayaan nasional) yang tidak memperoleh keuntungan.

2) Digunakan untuk kuburan, peninggalan purbakala atau penggunaan tanah dan bangunan yang serupa.

3) Hutan lindung, hutan wisata, hutan suaka alam, taman nasional, tanah pengembalaan yang dikuasai desa, dan tanah negara yang belum terbebani suatu hak.

4) Digunakan oleh perwakilan diplomatic, konsulat berdasarkan perlakuan asas timbal balik.

5) Digunakan oleh badan atau perwakilan organisasi internasional yang ditentukan oleh Menteri keuangan. ${ }^{20}$

f. Bea perolehan ha katas tanah dan bangunan (BPHTB)

Perolehan ha katas tanah atau bangunan adalah perbuatan atau peristiwahukum yang mengakibatkan diperolehnya hak atas tanah dan atau bangunan oleh orang priadi atau badan. ${ }^{21}$

19 Undang-Undang Negara Republik Indonesia Nomor 13 Tahun 1985 Tentang Bea Meterai. Pasal 1 ayat 1

20 Undang-Undang Republik Indonesia Nomor 12 Tahun 1994 Tentang Perubahan Atas Undang-Undang Nomor 12 Tahun 1985 Tentang Pajak Bumi Dan Bangunan. Pasal 3 ayat 1

21 Undang-Undang Republik Indonesia Nomor 20 Tahun 2000 Tentang Perubahan Atas Undang-Undang Nomor 21 Tahun 1997 Tentang Bea Perolehan Hak Atas Tanah Dan Bangunan. Pasal 1 ayat 2 
Sedangkan pajak daerah adalah pajak yang ditarik dan dikelola oleh daerah, baik pemerintah provinsi ataupun pemerintah kabupaten/kota yang meliputi:

a. Pajak provinsi

1) Pajak kendaraan bermotor dan kendaraan diatas air

2) Bea balik nama kendaraan bermotor dan kendaraan diatas air.

3) Pajak bahan bakar kendaraan bermotor

4) Pajak pengambilan danpemanfaatan air bawah tanah dan air permukaan.22

b. Pajak Kabupaten/kota

1) Pajak hotel

2) Pajak restaurant

3) Pajak hiburan

4) Pajak reklame

5) Pajak penerangan jalan

6) Pajak pengambilan bahan galian golongan $\mathrm{C}$.

7) Pajak parkir. ${ }^{23}$

\section{Fungsi pajak}

Sebagaimana dijelaskan pajak merupakan sumber pendapatan terbesar negara, tentunya dengan jumlah yang sangat besar tersebut pajak dapat digunakan untuk berbagai hal yang berkaitan dengan kepemerintahan. Adapun menurut Rahayu pajak memiliki dua fungsi, yaitu:

a. Fungsi budgetair yaitu pajak merupakan sumber pendapatan negara yang dapat digunakan untuk pemenuhan kebutuhan negara.

b. Fungsi Regulerend yaitu perekonomian suatu negara dapat dikontrol melalui pajak. ${ }^{24}$

Sedangkan menurut harjanto fungsi pajak adalah sebagaiberikut:

\footnotetext{
22 Undang-Undang Republik Indonesia Nomor 28 Tahun 2009 Tentang Pajak Daerah Dan Retribusi Daerah, Pasal 1 ayat 12-17

${ }^{23}$ Ibid, Pasal 1 ayat 20-31

24 Siti Kurnia Rahayu. Perpajakan Indonesia : Konsep \& Aspek Formal. (Yogyakarta: Graha Ilmu, 2013) hal 26.
} 
a. Fungsi anggaran, pajak berfungsi sebagai sumber pendapatan negara, dana pajak dapat digunakan untuk membiayai kebutuhan pengeluaran negara.

b. Fungsi mengatur (regulated), Pemerintah bisa mengatur pertumbuhan ekonomi melalui kebijaksanaan pajak.

c. Fungi stabilitas, dana pajak dapan digunakan oleh pemerintah dalam menjalankan dan menetapkan kebijakan, hal ini berkaitan dengan pengendalian inflasi dan stabilitas harga oleh pemerintah.

d. Fungsi redistribusi pendapatan, dana pajak dapat digunakan untuk membagun kepentingan dan fasilitas umum sehingga dapat membuka lapangan kerja baru untuk meningkatkan pendapatan masyarakat. ${ }^{25}$

\section{Analisis zakat dan pajak dalam mengatasi permasalahan}

\section{ekonomi nasional}

\section{Persamaan zakat dan pajak}

Secara konsep zakat maupun pajak merupakan suatu iuran yang dibayarkan masyarakan guna dikelola dan didistribusikan oleh negara sesuai peruntukannya, zakat untuk disalurkan kepada delapan asnaf sedangkan pajak dapat digunakan untuk pembangunan negara guna memfasilitasi warganya. Adapun persamaan zakat dan pajak menurut Zensudarno adalah sebagai berikut :

a. Zakat dan pajak bersifat wajib dan mengikat.

b. Pengumpulan zakat dan pajak dilakukan oleh lembaga resmi agar pengumpulan maupun penyalurannnya berjalan baik dan maksimal.

c. Negara dengan pemerintahan islam, zakat dan pajak dikelola negara.

25 Totok Harjanto, SE.,M.Tp. 2013. Pajak Dalam Pembangunan Ekonomi Nasional. JURNAL EKONOMI ISSN: 2302-7169 Vol. 6 Edisi 4 SeptemberDesember 2013 
d. Zakat dan pajak bertujuan untuk menyelesaikan permasalahan ekonomi negara. ${ }^{26}$

\section{Perbedaan Zakat dengan Pajak}

Penjelasan mengenai beberapa persamaan antara zakat dan pajak tidak berarti zakat dapat disamakan begitu saja dengan pajak. Terdapat perbedaan secara mendasar antara zakat dan pajak sehingga kedua aspek ini tidak bias disamakan. ${ }^{27}$ Zensudarno menjelaskan perbedaan-perbedaan antara zakat dan pajak dengan table berikut:

\begin{tabular}{|c|c|c|}
\hline \multicolumn{3}{|c|}{ Perbedaan Zakat Dan Pajak } \\
\hline Perbedaan & Zakat & Pajak \\
\hline Arti & $\begin{array}{l}\text { Bertambah dan } \\
\text { berkembang. }\end{array}$ & Utang, pajak, upeti. \\
\hline Dasar hukum & Al-Quran dan Hadits & Undang-undang negara \\
\hline $\begin{array}{l}\text { Nisab dan } \\
\text { tarif }\end{array}$ & $\begin{array}{l}\text { Mutlak atas ketentuan } \\
\text { Allah }\end{array}$ & $\begin{array}{l}\text { Relatif, sesuai dengan } \\
\text { neraca anggaran. }\end{array}$ \\
\hline Sifat & $\begin{array}{l}\text { Wajib dan terus } \\
\text { menerus }\end{array}$ & $\begin{array}{l}\text { Dapat dihapuskan sesuai } \\
\text { dengan keutuhan dan } \\
\text { keputusan pemerintah. }\end{array}$ \\
\hline Subyek & Muslim & Seluruh warga negara \\
\hline $\begin{array}{l}\text { Obyek alokasi } \\
\text { penerima }\end{array}$ & $\begin{array}{l}\text { Delapan golongan } \\
\text { (asnaf) }\end{array}$ & $\begin{array}{l}\text { Pembangunan dan } \\
\text { anggaran pemerintah }\end{array}$ \\
\hline $\begin{array}{l}\text { Harta yang } \\
\text { dikenakan }\end{array}$ & Harta produktif & Semua harta \\
\hline $\begin{array}{c}\text { Syarat Ijab- } \\
\text { kabul }\end{array}$ & Disyaratkan & Tidak disyaratkan \\
\hline Imbalan & $\begin{array}{c}\text { Harta yang bersih dan } \\
\text { barokah serta pahala } \\
\text { dari Allah }\end{array}$ & $\begin{array}{c}\text { Tersedianya Barang dan } \\
\text { jasa publik }\end{array}$ \\
\hline Sanksi & $\begin{array}{c}\text { dari Allah atas } \\
\text { kelalaian terhadap } \\
\text { kewajiban }\end{array}$ & Dari negara \\
\hline
\end{tabular}

\footnotetext{
26 Zensudarno, Beda Pajak Dan Zakat, http:/ / zensudarno.wordpress.com/2007/07/03/beda-pajak-dan-zakat/, diakses 7 Juli 2019.

${ }^{27}$ Ibid.
} 


\begin{tabular}{|c|c|c|}
\hline Motivasi & $\begin{array}{c}\text { Keimanan dan } \\
\text { ketaqwaan }\end{array}$ & $\begin{array}{c}\text { Kewajiban sebagai } \\
\text { warga negara, karena } \\
\text { pembayaran pajak } \\
\text { dimungkinkan adanya } \\
\text { manipulasi besarnya } \\
\text { jumlah harta wajib pajak. }\end{array}$ \\
\hline Perhitungan & $\begin{array}{c}\text { Perhitungan sendiri } \\
\text { atau menggunkan } \\
\text { bantuan amil }\end{array}$ & $\begin{array}{c}\text { Menggunakan jasa } \\
\text { akuntan pajak }\end{array}$ \\
\hline
\end{tabular}

Sumber : $\underline{\text { http://zensudarno.wordpress.com }}$

\section{Zakat dalam mengentaskan kemiskinan}

Indonesia sebagai negara dengan penduduk muslim terbesar di dunia. Sekitar $86 \%$ dari total jumlah penduduknya beragama islam. Bila melihat besarnya jumlah penduduk muslim yang ada di indonesia tentunya dapat dijadikan gambaran bahwa indonesia memiliki potensi zakat yang besar, hal ini ditinjau bahwa setiap muslim diwajibkan mengeluarkan 2,5\% dari hartanya untuk zakat bila harta tersebut telah mencapai syarat dan ketentuannya.

Potensi zakat diestimasikan atas PDB negara, karena dengan naiknya tingkat PDB maka dapat disimpulkan terdapat kenaikan pula pada tingkat pendapatan ataupun tingkat pereknomian baik pada sebagian ataupun sekelompok individu. Terdapat perbedaan atas persentase estimasi potensi zakat atas PDB, diantaranya adalah sebagai berikut:

a. Penelitian PBB UIN Syarif Hidayatullah tahun 2005 mengestimasi potensi filantropi islam di Indonesia mencapai Rp. 19,3 trilyun atau sebesar 0,8\% dari PDB tahun 2004

b. Penelitian BAZNAS-IRTI IDB tahun 2012 menjelaskan potensi zakat Indonesia mencapai Rp. 217 trilyun atau sebesar 3,4\% dari PDB tahun 2010.

c. Penelitian Wibisono tahun 2015 menjelaskan potensi zakat di Indonesia pada tahun 2010 mencapai Rp. 106,6 trilyun atau 1,7\% dari PDB tahun 2010.28

28 Yusuf Wibisono. 2016. Potensi Zakat Nasional: Peluang dan Tantangan Pengelolaan Makalah disampaikan pada Seminar Nasional Zakat 2016, 
Selanjutnya dengan beberapa penyesuaian yang dilakukan oleh baznas menyimpulkan estimasi potensi zakat pada 2015 mencapai 286 trilyun (2,4\% dari PDB 2015). Dengan persentase demikian, maka perkiraan potensi zakat 2016 adalah 442 triliun (3,4\% dari PDB 2016), 221 triliun (1,7\% dari PDB 2016), dan 104 triliun (0,8\% dari PDB 2016). ${ }^{29}$

Berapapun estimasi yang diperkirakan, menunjukkan bahwa zakat memiliki potensi yang sangat besar untuk mengatasi permasalahan kemiskinan di Indonesia, dimana diketahui bahwa salah dua penerima zakat adalah fakir dan miskin.

Dengan potensi yang besar tersebut bila dapat dikelola dan didistribusikan dengan baik, maka cepat atau lambat akan menjadi solusi dari permasalahan kemiskinan yang ada. Potensi zakat yang diambil pada perkiraan estimasi terendah yaitu 104 triliun $(0,8 \%$ dari PDB) bila dibagi dengan jumlah penduduk miskin 28,1 juta jiwa maka per individu akan mendapatkan tambahan dana sebesar Rp. 3,71 juta. Dengan demikian secara otomatis penerima zakat (mustahik zakat) tersebut mendapatkan tambahan dana untuk meningkatkan perekonomian, baik guna dikonsumsi maupun guna di produktifkan.

Penelitian sebelumnya menjelaskan bahwa di Indonesia zakat memiliki potensi yang sangat besar. Namun disisi lain terdapat kendala besar yang harus dihadapi yaitu pada pengumpulan dana zakat. Lembaga amil zakat pemerintah dan swasta masih belum mampu mengumpulkan dana zakat dalam jumlah yang besar. ${ }^{30}$ Estimasi dan perkiraan atas potensi zakat tersebut hanya menjadi perhitungan semata dimana zakat yang terkumpul hanya terserah kurang lebih 3\% dari potensi yang ada. Distribusi zakat yang tidak merata, distribusi secara pribadi, serta kesadaran masyarakat akan kewajiban membayar zakat yang masih minim menjadikan potensi

diselenggarakan oleh PUSKAS BAZNAS dan PEBS FEBUI. Depok, 8 Desember 2016.

${ }^{29}$ Ibid.

${ }^{30}$ Firmansyah, 2013. Zakat sebagai instrumen pengentasan kemiskinan dan Kesenjangan pendapatan. Jurnal Ekonomi dan Pembangunan Vol 21, No. 2, Desember lihat Made Warka and Erie Hariyanto, "Kedudukan Bank Syariah Dalam Sistem Perbankan Di Indonesia," IQTISHADIA: Jurnal Ekonomi \& Perbankan Syariah, 2016, https://doi.org/10.19105/iqtishadia.v3i2.1076. 
besar zakat hanya sekedar angka semata. Bila potensi zakat tepenuhi, maka dalam waktu yang singkat permasalahan kemiskinan di indonesia akan teratasi.

\section{Pajak dalam pembangunan infrastruktur}

Pajak merupakan komponen terbesar pada penerimaan negara, tahun 2016 pendapatan negara yang diperoleh dari pajak sebesar Rp. $1.283,6$ triliun, jika di persentasikan pajak yang terkumpul sebesar 83,4\% dari penerimaan pajak yang ditargetkan yaitu Rp. 1.539,17 triliun. Pendapatan negara pada tahun 2016 adalah sebesar Rp. $1.551,78$ triliun, dan $82,72 \%$ dari pendapatan negara tersebut bersumber dari penerimaan pajak negara. ${ }^{31}$ Walaupun tidak $100 \%$ mencapai penerimaan yang ditargetkan, penerimaan pajak yang mecapai $82,72 \%$ dari total pendapatan negara mengindikasikan bahwa pajak memiliki peran yang sangat besar guna membiayai segala macam belanja negara, mengingat pajak dapat dialokasikan kepada berbagai sektor, salah satu yang membedakan pajak dan zakat adalah jika pajak dapat dialokasikan ke segala macam belanja ataupun kebutuhan negara, zakat hanya dapat dialokasikan kepada delapan asnaf yang telah ditentukan.

Apabila besarnya penerimaan negara dapat dialokasikan dan dikelola dengan baik maka pembangunan maupun perbaikan infrastruktur akan berjalan dengan baik dan efektif yang nantinya dapat meningkatkan pertumbuhan ekonomi negara. dengan demikian pajak memiliki kontribusi yang besar bagi perekonomian negara, dan yang dibutuhkan adalah peran aktif pemerintah dalam pengalokasian serta pengelolaan penerimaan negara. menurut penulis pemerintah perlu memprioritaskan pada pembangunan atau perbaikan infrastruktur sebab dengan infrastruktur yang baik maka alur jalannya perkonomian dapat diserap dengan baik pula sehingga nantinya dapat berdampak pada terciptanya lapangan kerja yang baru.

\section{Kesimpulan}

Zakat maupun pajak memiliki peran penting pada pertumbuhan ekonomi negara. Zakat berjalan melalui sisi mikro,

31 http://databoks.katadata.co.id/datapublish/2017/01/11/ diakses 10 juli 2019 
yaitu zakat dapat memperbaiki perekonomian masyarakat yang termasuk pada delapan asnaf serta dapat menghilangkan kesenjangan sosial antara pihak surplus dana dengan pihak defisit dana atau dengan kata lain zakat dapat dijadikan sebagai media pendistribusian kekayaan yang efektif. Sedangkan pajak berjalan pada sisi makro, yaitu penerimaan negara yang sebagian besar diterima dari zakat dapat digunakan untuk berbagai macam belanja, pembangunan ataupun untuk kebutuhan negara lainnya.

Zakat dan pajak yang seharusnya dapat berdampak besar bagi perekonomian negara terhalang pada pengumpulannya, dimana zakat hanya terkumpul sekitar 3\% dari potensi yang ada, sementara pajak hanya terkumpul $83,4 \%$ dari total penerimaan pajak yang ditargetkan.

\section{Daftar Pustaka}

\section{Al-Quran}

\section{Buku:}

Nuruddin, Ali. Zakat Sebagai Instrumen Dalam Kebijakan Fiskal. Jakarta: Pt Raja Grafindo Persada. 2006.

Warka, Made, and Erie Hariyanto. "Kedudukan Bank Syariah Dalam Sistem Perbankan Di Indonesia." IQTISHADIA: Jurnal Ekonomi \& Perbankan Syariah, 2016.

Hafidhuddin, Didin. Zakat dalam Perekonomian Modern. Jakarta : Gema Insani Press. 2002.

Rais, M. Amien. Kemiskinan Dan Kesenjangan Di Indonesia. Jakarta: Aditya Media. 1995.

Latief, Moh. Rowi \& A. Shomad Robith. Tuntunan Zakat Praktis. Surabaya: Indah. 1987.

Ali, Mohammad Daud. Sistem Ekonomi Islam Zakat dan Wakaf. Jakarta : UI Press. 1988.

Brotodiharjo, R. Santoso. Pengantar Ilmu Hukum Pajak. Bandung: Rafika Aditama. 2003.

Rahayu, Siti Kurnia. Perpajakan Indonesia : Konsep E Aspek Formal. Yogyakarta: Graha Ilmu. 2013.

Qardhawi, Yusuf. Kiat Sukses Mengelola Zakat, Terj. Asmuni Solihan Zamakhsyari. Jakarta: Media Dakwah. 1997. 


\section{Jurnal}

Firmansyah, "Zakat sebagai instrumen pengentasan kemiskinan dan Kesenjangan pendapatan". Jurnal Ekonomi dan Pembangunan Vol 21, No. 2, Desember 2013.

Hariyanto, Erie; Suyudi Mohammad. "View of Jual Beli Benda Wakaf Untuk Pembangunan Masjid Istiqlal Di Desa Palengaan Daja Pamekasan." Accessed January 26, 2020.

Hariyanto, Erie, and Moh Ali Al-Humaidy. "Pelaksanaan Corporate Social Responsibility Dan Zakat Perusahaan Perbankan Syari'ah Di Madura Erie Hariyanto, Moh. Ali Al-Humaidy", Jurnal Hukum \& Pembangunan 49, no. 3 (2019): 688709.http://dx.doi.org/10.21143/

Hasanuz Zaman, S. M., "Islamic Criteria For The Distribution Of Tax Burden (The Mix of Direct and Indirect Taxes and The Offsetting Fuction of Zakat)", Journal of Islamic Economics, Vol. 3, No. 1. Januari Tahun 1993.

Monzer Kahf, Potential Effects Of Zakah On Government Budget, Journal of Economics E Management Vol. 5, No. 1. Tahun 1997.

Novi Maryaningsih, Oki Hermansyah, dan Myrnawati Savitri. "Pengaruh Infrastruktur Terhadap Pertumbuhan Ekonomi Indonesia". Buletin Ekonomi Moneter dan Perbankan, Volume 17, Nomor 1, Juli 2014

Totok Harjanto, SE.,M.Tp. Pajak Dalam Pembangunan Ekonomi Nasional. JURNAL EKONOMI ISSN: 2302-7169 Vol. 6 Edisi 4 SeptemberDesember 2013

\section{Peraturan Perundang-Undangan}

Undang-Undang Negara Republik Indonesia Nomor 13 Tahun 1985 Tentang Bea Meterai. Pasal 1 ayat 1

Undang-Undang Negara Republik Indonesia tentang Pajak Daerah Dan Retribusi Daerah, Pasal 1 ayat 20-31

Undang-Undang Republik Indonesia Nomor 12 Tahun 1994 Tentang Perubahan Atas Undang-Undang Nomor 12 Tahun 1985 Tentang Pajak Bumi Dan Bangunan. Pasal 3 ayat 1

Undang-Undang Republik Indonesia Nomor 18 Tahun 2000 Tentang Perubahan Kedua Atas Undang-Undang Nomor 8 Tahun 1983 Tentang Pajak Pertambahan Nilai Barang Dan Jasa Dan Pajak Penjualan Atas Barang Mewah, Pasal 1 ayat 1. 
Undang-Undang Republik Indonesia Nomor 18 Tahun 2000 Tentang Perubahan Kedua Atas Undang-Undang Nomor 8 Tahun 1983 Tentang Pajak Pertambahan Nilai Barang Dan Jasa Dan Pajak Penjualan Atas Barang Mewah, Pasal 5 ayat 2.

Undang-Undang Republik Indonesia Nomor 20 Tahun 2000 Tentang Perubahan Atas Undang-Undang Nomor 21 Tahun 1997 Tentang Bea Perolehan Hak Atas Tanah Dan Bangunan. Pasal 1 ayat 2

Undang-Undang Republik Indonesia Nomor 23 Tahun 2011 Tentang Pengelolaan Zakat, Pasal 4 ayat 1

Undang-Undang Republik Indonesia Nomor 28 Tahun 2009 Tentang Pajak Daerah Dan Retribusi Daerah, Pasal 1 ayat 12-17

Undang-Undang Republik Indonesia Nomor 7 Tahun 1983 Tentang Pajak Penghasilan, Pasal 1

\section{Web}

Ahmad Hadi Yasin. "Panduan zakat praktis" (hak cipta dompet dhuafa republika). www.dompetdhuafa.org. Diakses 8 juli 2019. http://databoks.katadata.co.id/datapublish/2017/01/11/ diakses 10 juli 2019

http:// pelayanan-pajak.blogspot.co.id, diakses 8 juli 2017.

https://id.wikipedia.org/wiki/Perpajakan_di_Indonesia. diakses 17 juli 2019

https://www.bps.go.id diakses 2 juli 2019

Zensudarno, Beda Pajak Dan Zakat, http://zensudarno.wordpress.com/2007/07/03/beda-pajak-danzakat. diakses 7 Juli 2019. 